\title{
An Experimental Study of the Uptake and Loss of Radioactive Cesium by Mussel (Mytilus galloprovincialis)
}

\author{
Varinlioglu $\mathbf{A}^{1}$, Turhan $\mathbf{S}^{2^{*}}$ and Karatasl $\mathbf{M}^{1,3}$
}

${ }^{1}$ Cekmece Nuclear Research and Training Center, Atatürk Airport Istanbul, Turkey

${ }^{2}$ Department of Physics, Faculty of Science and Letters, University of Kastamonu, 37150 Kastamonu, Turkey

${ }^{3}$ Institute of Science, University of Cukurova, Balcal, Adana, Turkey

\begin{abstract}
The uptake of radioactive cesium by mussels, Mytilus galloprovincialis, collected from Marmara Sea exposed over one month to radioactive contaminated sea water and the subsequent loss in non-radioactive sea water were studied with 137Cs. The uptakes and losses of 137Cs by mussels observed experimentally were plotted and fit to appropriate functions. The experiments clearly showed that the activity concentrations of $137 \mathrm{Cs}$ in mussels reached a peak which is a saturation state in 30 days while the loss of a substantial of the $137 \mathrm{Cs}$ activity by mussels was observed within 15 days. The activity concentrations of $137 \mathrm{Cs}$ in soft parts of the mussels were higher than those measured in whole body of the mussels.
\end{abstract}

Keywords: ${ }^{137}$ Cs; Mussel; Mytilus galloprovincialis; Uptake; Loss; Marmara sea

\section{Introduction}

The radioactivity contamination of marine waters and coastal ocean is a major concern in many countries due to the development of nuclear facilities including nuclear power plants, fuel reprocessing plants and waste disposal installations [1]. In addition, the fallouts from nuclear accidents (Chernobly and Fukushima) and nuclear weapon testing have resulted in the release of many radionuclides into aquatic environments. Among the many radionuclides, radioactive cesium $\left({ }^{137} \mathrm{Cs} ; \mathrm{T}_{1 / 2}=30.2\right.$ years $)$ is present in fallout and also commonly found in nuclear waste.

The bioaccumulation, depuration and biokinetics of many radionuclides including ${ }^{137} \mathrm{Cs}$ in aquatic organisms have been studied in the literature [2-13]. The present study reports an experimental study to the rates of uptake and loss of ${ }^{137} \mathrm{Cs}$ by mussels (Mytilus galloprovincialis) exposed over one month to radioactive contaminated sea water.

\section{Materials and Methods}

Sixty individuals of Mytilus galloprovincialis (5-7 cm in shell length) were caught from Marmara Sea. Size of the mussels selected varied between 4 and $6 \mathrm{~cm}$. All mussel samples were washed and cleaned with marine water. Thus the mussels were removed from algae found in their natural environment. Then the mussels were kept in an aquarium (1.2 meters long, 0.5 meters wide and 0.8 meters in height) filled with 7 liters of sea water and the starfish taken from Marmara for feeding with phytoplankton, and 53 liters of clean water mixed with $1 \mathrm{~kg}$ of sea salt. Water in the aquarium remains clean and prevents putrefaction with help of the skimmer. For the uptake experiment ${ }^{137} \mathrm{Cs}$ was added in to the aquarium to provide a concentration of $150 \mathrm{~Bq} \mathrm{l}^{-1}$. The some mussel shells were opened and the soft tissue was extracted from the shells. The whole body and soft tissue uptake of ${ }^{137} \mathrm{Cs}$ by the mussels exposed to contaminated water were followed for 32 days. After uptake experiments the mussels in the aquarium were transferred to another aquarium filled with 8 liters of sea water and the starfish, and 53 liters of clean water mixed with $1 \mathrm{~kg}$ of sea salt for loss experiments. The whole body losses of ${ }^{137} \mathrm{Cs}$ by the mussels were followed for 15 days.

Activity concentrations of ${ }^{137} \mathrm{Cs}$ in mussels were measured using a high-resolution gamma-ray spectrometer with a coaxial p-type HPGe detector (Canberra GX3018) at the Radioactivity Measurement and Analysis Unit of Çekmece Nuclear Research and Training Center. The energy resolution of the HPGe detector is $1.8 \mathrm{keV}$ at $1332.5 \mathrm{keV}$ of ${ }^{60} \mathrm{Co}$ gamma energy with a relative efficiency of $30 \%$. The energy-dependent efficiency calibration was carried out using a multinuclide standard source (Isotope Products Laboratories). The activity concentration of ${ }^{137} \mathrm{Cs}$ was determined directly from the peak areas at $661.6 \mathrm{keV}$.

\section{Results}

Activity measurements of ${ }^{137} \mathrm{Cs}$ in whole body and tissue were performed for three mussels taken from contaminated aquarium. Activity concentrations of ${ }^{137} \mathrm{Cs}$ in whole body and soft tissue of mussels measured for different days are presented in Table 1. Also, uptakes of ${ }^{137} \mathrm{Cs}$ in whole bodies and tissues of mussels are shown in Figure 1. From Table 1, the activity concentrations of ${ }^{137} \mathrm{Cs}$ in whole body and soft tissue varied from 58 to $149 \mathrm{~Bq} \mathrm{~kg}^{-1}$ in dry wt. and 38 to $96 \mathrm{~Bq} \mathrm{~kg}^{-1}$ in dry wt., respectively for uptake experiment. It can be seen from Figure 1 that the final uptake values obtained after a 32-day exposure were $149 \mathrm{~Bq} \mathrm{~kg}^{-1}$ and $96 \mathrm{~Bq} \mathrm{~kg}^{-1}$ for whole body and tissue, respectively. The data of the uptakes experiments have good fit to logarithmic functions shown on Figure 1.

Activity concentrations of ${ }^{137} \mathrm{Cs}$ in whole bodies of the mussels measured for the loss experiment are presented in Table 2 and Figure 2. From Table 2, the activity concentrations of ${ }^{137} \mathrm{Cs}$ measured in whole bodies varied from 3 to $149 \mathrm{~Bq} \mathrm{~kg}^{-1}$ in dry wt. It can be seen from Figure 2 that the final loss value obtained after a 15-day was $3 \mathrm{~Bq} \mathrm{~kg}^{-1}$. The data of the uptakes experiments have good fit to logarithmic functions shown on Figure 1. The loss experimental data were fitted to the second

*Corresponding author: Turhan S, Department of Physics, Faculty of Science and Letters, University of Kastamonu, 37150 Kastamonu, Turkey, Tel: 90366280 19 40; Fax: 9036621549 69; E-mail: serefturhan63@gmail.com

Received July 10, 2015; Accepted August 04, 2015; Published August 10, 2015

Citation: Varinlioglu A, Turhan S, Karatasl M (2015) An Experimental Study of the Uptake and Loss of Radioactive Cesium by Mussel (Mytilus galloprovincialis). J Environ Anal Toxicol 5: 314. doi:10.4172/2161-0525.1000314

Copyright: (c) 2015 Varinlioglu A, et al. This is an open-access article distributed under the terms of the Creative Commons Attribution License, which permits unrestricted use, distribution, and reproduction in any medium, provided the original author and source are credited. 
Citation: Varinlioglu A, Turhan S, Karatasl M (2015) An Experimental Study of the Uptake and Loss of Radioactive Cesium by Mussel (Mytilus galloprovincialis). J Environ Anal Toxicol 5: 314. doi:10.4172/2161-0525.1000314

\begin{tabular}{|c|c|c|}
\hline \multirow{2}{*}{ Days } & \multicolumn{2}{|c|}{ Activity concentration of ${ }^{{ }^{137} \mathbf{C s}\left(\mathbf{B q ~}^{\mathbf{1}} \mathbf{)}\right)}$} \\
\cline { 2 - 3 } & Whole body & 38 \\
\hline 1 & 58 & 56 \\
\hline 3 & 85 & 65 \\
\hline 5 & 98 & 74 \\
\hline 8 & 114 & 82 \\
\hline 12 & 127 & 88 \\
\hline 17 & 138 & 95 \\
\hline 28 & 148 & 96 \\
\hline 32 & 149 & \\
\hline
\end{tabular}

Table 1: Dry-weighted-based activity concentration of ${ }^{137} \mathrm{Cs}$ in the mussels for uptake experiment.

\begin{tabular}{|c|c|}
\hline Days & Activity concentration of ${ }^{{ }^{137} \mathbf{C s}\left(\mathbf{B q ~}_{\mathbf{~ k g}}{ }^{-1}\right)}$ \\
\hline 1 & 149 \\
\hline 3 & 117 \\
\hline 5 & 82 \\
\hline 8 & 39 \\
\hline 10 & 22 \\
\hline 13 & 7 \\
\hline 15 & 3 \\
\hline
\end{tabular}

Table 2: Dry-weighted-based activity concentration of ${ }^{137} \mathrm{Cs}$ in the mussels for loss experiment.



Figure 1: The uptakes of ${ }^{137} \mathrm{Cs}$ by whole bodies and tissues of mussels.

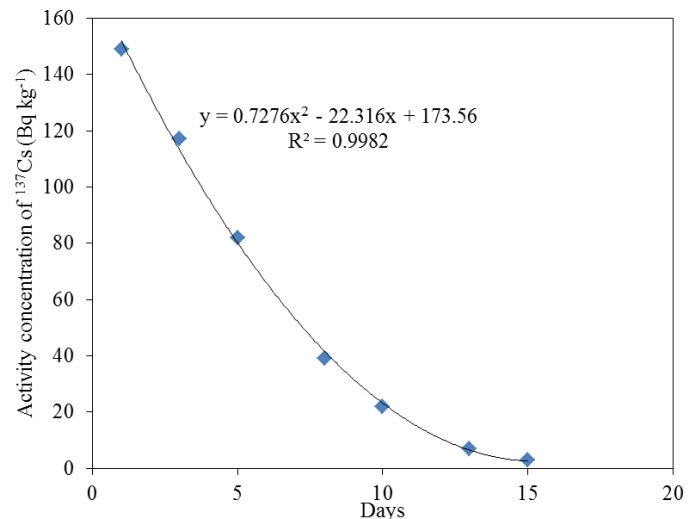

Figure 2: The loses of ${ }^{137} \mathrm{Cs}$ by whole bodies of mussels. order polynomial shown on Figure 2 .

\section{Discussion}

This is the first study related to the uptake and loss of ${ }^{137} \mathrm{Cs}$ by mussel done in Turkey.

The results of the uptake experiment show that the mussels were exposed to radioactivity at the maximum rate after 3 days. The activity concentrations of ${ }^{137} \mathrm{Cs}$ measured in whole body were $35 \%$ higher those measured in the soft tissue of the mussels. The activity concentrations of ${ }^{137} \mathrm{Cs}$ in mussels reached to the saturation state after 30 days. The results of the loss experiment show that $t$ the loss of a substantial of the ${ }^{137} \mathrm{Cs}$ activity by mussels exposed to radioactivity was observed within 15 days.

\section{Acknowledgements}

The authors wish to thank Turkish Atomic Energy Authority (TAEA).

\section{References}

1. Ke C, Yu KN, Lam PKS, Wang WX (2000) Uptake and depuration of cesium in the green mussel Perna viridis. Mar Biol 137: 567-575.

2. Schults-Baldes $M$, Cheng $L$ (1979) Uptake and loss of radioactive cadmium by the sea-skater Halobates robustus (Heteroptera: Gerridae). Mar Biol 52 : 253-258.

3. Baumann Z, Casacuberta N, Baumann H, Masqué P, Fisher NS (2013) Natura and Fukushima-derived radioactivity in macroalgae and mussels along the Japan shoreline. Biogesciences 10: 3890-3815.

4. Boisson F, Cotret O, Fowler SW (1998) Bioaccumulation and retention of lead in the mussel Mytilus galloprovincialis following uptake from seawater. Sci Total Environ 222: 55-61.

5. Bustamante P, Teyssié JL, Fowler SW, Warnau M (2006) Assessment of the exposure pathway in the uptake and distribution of americium and cesium in cuttlefish (Sepia officinalis) at different stages of its life cycle. J Exp Mar Biol Ecol 331: 198-207.

6. Carvalho FP (2011) Polonium (210Po) and lead (210Pb) in marine organisms and their transfer in marine food chains. J Environ Radioact 102: 462-472.

7. Desideri D, Meli MA, Roselli C, Feduzi L (2009) A biomonitoring study: 210Po and heavy metals in mussels. J Radioanal Nucl Chem 279: 591-600.

8. Güngör N, Tuğrul B, Topcuoğlu S, Güngör E (2001) Experimental studies on the biokinetics of $134 \mathrm{Cs}$ and $24 \mathrm{Am}$ in mussels (Mytilus galloprovincialis). Environ Int 27: 259-264.

9. Hewett CJ, Jefferies DF (1976) The accumulation of radioactive caesium from water by the brown trout (Salmo trutta) and its comparison with plaice and rays J Fish Bio 9: 479-489.

10. Jeffree R, Simpson RD (1986) An experimental study of the uptake and loss of Ra-226 by the tissue of the tropical freshwater mussel Velesunio angasi (Sowerby) under varying $\mathrm{Ca}$ and $\mathrm{Mg}$ water. Hydrobiologia 138: 59-80.

11. Kilic O, Cotuk Y (2011) Radioactivity concentrations in sediment and mussel of Bosphorus and Golden Horn. J Radioanal Nucl Chem 289: 627-635.

12. Onat B, Topcuoglu S (1999) A laboratory study of $\mathrm{Zn}$ and ${ }^{134} \mathrm{Cs}$ depuration by the sea snail (Rapana venosa). J Environ Radioact 46: 201-206.

13. Topcuoglu S, Van Dowen AM (1997) A study on elimination ${ }^{134} \mathrm{Cs}$ in mussels under contaminated field and laboratory conditions. Toxicol and Environ Chem 58: $217-222$ 